lations, as far seemingly as they affect the medical department, first the spirit was broken, then the letter, till at the present time this regulation has come to be utterly disregarded; and in all ships now fitting out, in which there are main deck cabins, in not a single instance is the principal medical officer allowed to have one, while in all accommodation is here provided for the paymaster and chaplain, irrespective entirely of their standing in the service. In one notable instance room has also been found for the senior marine officer and the admiral's steward. When it is remembered that in all ships of this class the senior medical officers must hold the relative rank of lieut. colonel, our civil brethren can understand the advantages that appertain to rank and length of service in the medieal department of the navy.

This question, as I said before, affects prejudicially not only the comfort, but the social position which it is imperative the principal medical officer of a ship should have. The moment a young officer joins the service he is struck with the present anomaly, and says-"Here is a staff surgeon of twenty or thirty years' service occupying exactly the same position as I do ; what have I to look forward to ?" That these remarks are of every-day occurrence all in the service must be aware. Accordingly he makes up his mind to resign. Then comes the refusal to accept his resiguation. Desertion and trial by Court Martial have in some well-known instances followed; while in others a sullen acceptance of the situation is the result, waiting for the opportunity which half-pay affords to decline taking up another appointment. This, however, has been met by their lordships by " Dismissal for refusing to serve." Such is the present state of the department, and until a thorough change takes place in it, by grauting to medical officers that consideration and position to which they are socially entitled as members of one of the first of professions, it is not a service to which any young medical man should turn his attention.

When more judicious counsels prevail, and medical officers occupy their proper position on board H.M. ships, it will be equally the duty of those serving to make the profession acquainted with the change, and to invite our younger brethren to join, as it is now our interest to proclaim, by every channel throughout the country, our advice to them to abstain from doing so. Yours, \&c.,

Nov, 30th, 1874.

Natricus.

\section{CHARITY ELECTIONEERING.}

To the Editor of THE LANCET.

SIR,-We are grateful for the "hearty sympathy" you express for our attempt to " break the neck of the costly and mischievous system of canvassing "in the disposal of charitable benefits, but are disappointed at the remarks which follow. Considering the "very large number of subscribers of different creeds, classes, and proclivities" with which we have to deal, we thought we had indicated with all practicable precision what the future action ought to be. The only possible alterrative for voting by the whole body of the subscribers is the investigation and classification of the claims of the candidates by a responsible Committee. This was accordingly prominently recommended by us; whether the Committee charged with the duty were the ordinary managing Committee, or a Sub-Committee of it, or a special Committee appointed $a d$ hoc by the subscribers. Meanwhile we recommend that subscribers should entrust their votes to the Managing Committees of the respective institutions under the specific respon. sibility of investigating and classifying the cases of the candidates, and of using the votes in the order of the classified lists, and that, in the event of any managing Committee declining to accept this responsibility, the subscribers should select for their charitable donations other institutions not open to the same serious evils. - I am, \&c.

Iondon, November 30th.

C. E. Trevelyan.

\section{MR. BADER'S "NEW CATARACT KNIFE."} To the Editor of THE LANCHT.

SIR, - I am sorry to be obliged to set aside the claim of my friend Mr. Bader to have invented a "new" cataract knife. The right-hand knife of the pair which he describes was made for me by Messrs. Weiss about six years ago, and is still in my possession. On fair trial it seemed greatly to resemble the patent corkscrew, which had for its chief merit that it did not give much more trouble than the common one; and I soon relinquished its employment without giving an order for its lett-hand companion. But it is my "new" lnuife if it is anybody's.

I am, Sir, your obedient servant,

Wimpole-street, Nov. 28th.

R. Brudenell Carter.

\section{Gibituaty.}

SIR J. RANALD MARTIN, C.B., F.R.S.

WHEN we announced the resignation by Sir J. Ranald Martin of the appointment he had so long and honourably held at the India Office, we had no idea that we should so soon-within a few days afterwards-have to record his death, which took place at his residence in Upper Brookstreet on Friday, the 27th ult. Notwithstanding the years he had counted and the services he had seen, Sir Ranald Martin's tall and vigorous frame was scarcely, if at all, bowed by age; his intellect was clear, his manner urbane and cheerful, and his step firm up to the moment that he descended for the last time the staircase of the India House, where his presence on "Board days" and his friendly greeting had become, as it were, a part of the institution. The traces of the progressive enfeeblement of age were discernible in him, no doubt; but no one would have imagined from his appearance that his end was so near. His hearing had of late years grown somewhat defective, and he displayed, perhaps, a little more than his ordinary care in guarding against the effects of cold. He was accustomed to declare that the occurrence of a cold wind was sure to bring with it reminiscences of that malarious fever from which he had years before suffered in India, and he appeared to be more liable to attacks of catarrh during the winter. The changeable, cold, and foggy weather that prevailed, with such disastrous effects on the aged, gave rise to that attack of bronchitis and pulmonary congestion of which Sir Ranald perished, and from which it was hoped his intended departure from London might have saved him.

Sir Ranald was the son of the Rev. Donald Martin, of Kilmuir, Isle of Skye, where he was born in the year 1793. His mother was the eldest daughter of Norman Macdonald, Esq., of Scalpa, sister of the late Sir John Macdonald, G.C.B. He received bis early education at the Royal Academy, Inverness. In 1813 he came to London frow Inverness, and began his professional studies at St. George's Hospital, under Sir Everard Home and Sir Benjamin (then Mr.) Brodie. He entered the service of the Honourable East India Company, on the Bengal Medical Establishment, in 1817, from which time almost to the present his name has been connected with some work or other for the benefit of his countrymen in India and Europe. In 1821 he was appointed by the Governor-General surgeon to his body-guard, and served in two campaigns during the first Burmese War. In 1826 Mr. Martin married a daughter of Colonel Paton, C.B., Quartermaster General of the Bengal armp, and com. menced civil practice in Calcutta, where he met with great success and obtained the highest reputation. His practice in Calcutta was for many years most extensive. In 1830 he was appointed by the Governor-General, Lord W. Bentinck, Presidency Surgeon, and in November of the same year he was elected Surgeon to the General Hospital in Calcutta. This position afforded him great opportunities of witnessing the influence of a tropical climate on health and disease, and also of collecting materials for hiswell-known work on that subject. Up to 1838 he continued in active practice in Calcutta, when failing health necessitated change, and in 1840 he took his final leave of India amidst general and public expressions of regret. On his return to England he soon became engaged in the duties of a large practice, and his opinion was highly valued. He was appointed a sanitary commissioner in England in 1842 , and had on several occasions been employed by the Government to make investigation and report on subjects connected with sanitary science.

Sir Ranald's writings were numerous, and included "In- 